Religion and Gender, vol. 2, no. 2 (2012), pp.

305-327

www.religionandgender.org

URN:NBN:NL:UI:10-1-101605

ISSN: $1878-5417$

Publisher: Igitur Publishing (Utrecht)

Copyright: this work is licensed under a Creative

Commons Attribution License (3.0)

\title{
What Men Want? Initial Thoughts on the Male Goddess Movement
}

\author{
DAVID GREEN
}

\begin{abstract}
This article examines the sociological dynamics of a number of contemporary Pagan men who venerate goddesses. Rejecting both mythopoetic and normative Western social constructions of masculinity, the Male Goddess Movement (MGM) equates social problems with traits usually associated with masculinity such as aggression and competitiveness. The MGM is built around the interiorization of the female antitype as a form of liberation from these dogmas of masculinity. In this respect ritual practice centred on Goddesses becomes of central importance to the performance of non-essentialized and enchanted forms of masculinity. This interiorization and ritualization has importance for both theory and practice. In sociological terms the MGM marks a new form of gendered religious practice which deliberately resists epistemological labels such as 'modern' or 'postmodern'. Within Contemporary Paganisms it marks a new second wave of masculinist consciousness which, contrary to mythopoetic constructions of masculinity, seeks to dismantle essentialist forms of gender difference.
\end{abstract}

\section{Keywords}

Paganisms, masculinity, essentialism, mythopoesis, Goddess, antitype 


\section{Author affiliation}

Dave Green is a Senior Lecturer in Sociology at the University of the West of England, Bristol, UK. Email: David2.Green@uwe.ac.uk

\section{Introduction}

Throughout my research into Paganisms I have become aware of, and increasingly interested in, a group of Pagan men ${ }^{1}$ who, following the dominant feminine spiritual idiom ${ }^{2}$ of many Neo-Pagan paths, rooted their magico-religious practices in veneration of goddesses, rather than in mythopoetic constructions of masculinity. ${ }^{3}$ Although they are by no means a unified community of practitioners I began to term them The Male Goddess Movement (MGM). The MGM appears to be a new and unresearched phenomenon within Contemporary Paganisms. Indeed, whereas innovative interdisciplinary research has been conducted in relation to constructions of masculinity within other world religions, particularly in Christianity and Judaism, ${ }^{4}$ the few existing studies of masculinity within Paganisms provide one with a unilateral mythopoetic vision of Pagan men as instrumental hunters and providers who honour male deities and prize traditional masculine qualities such as strength, courage, competitiveness and stoicism. ${ }^{5}$

1 'Feminine'/'female' and 'masculine'/'male' are often used interchangeably throughout this article to refer to dominant Western social constructions of gender - and the inequalities involved - as opposed to the use of 'women' and 'men', which, in sociological convention, refer to humans as biological constructs. For a fuller explanation of this convention see, for example, Stephen M. Whitehead, Men and Masculinities, Cambridge: Polity Press 2002; Amy S. Wharton, The Sociology of Gender, Oxford: Wiley-Blackwell 2011.

2 This refers to the centrality of female divinity and feminist forms of praxis within mainstream Paganisms. See, for example, Starhawk, The Spiral Dance, San Francisco: Harper \& Row 1982.

3 See, for example, Gabriella Smith, 'The Wild/Green Man: Exploring the Mythopoetic Legacy within Modern Paganism's Constructions of Gender', 2008, available at http://www.allacademic.com//meta/p mla_apa_research_citation/2/4/2/3/7/pages 24 2370/p242370-1.php. Accessed 16 March 2011.

4 See for example, Björn Krondorfer (ed.), Men and Masculinities in Christianity and Judaism: A Critical Reader, Norwich: SCM Press 2011; also Yvonne Maria Werner, Christian Masculinity, Leuven: Leuven University Press 2011.

5 As I argue later in this article, the MGM demonstrates a tempering of these values through anti-essentialist practices which seek to interiorize traits and behaviours more conventionally seen as 'feminine'. An embryonic reflection on this temperance of mythopoetic masculinity can be found in Seth Mirsky, 'Men and the Promise of Goddess Spirituality', in Stephen B. Boyd, W. Merle Longwood and Mark W. Muesse 
Given this perceived gap in scholarship, this article aims to outline constructions of religious masculinity within Paganisms more generally, and the discourses and practices of the MGM more specifically. In particular, I was interested to discover more about the existential and liturgical influences of female deity within the MGM, especially how this impacted upon its discourses of gender equality and sexuality. The article begins with a personal encounter with one pagan man, 'John'. In the Spring of 2003, after using a snowballing approach to individuals involved in Goddess Spirituality, I received a phone call from him, and after several follow-up conversations he eventually invited me to his Wiltshire home in the rural south of England that summer. Following the outline of this encounter, the article proceeds to see how this fits into the feminization of divinity and the spiritual idiom that is characteristic of mainstream Paganisms.

\section{John}

A long taxi ride took me from the railway station to John's home, a cottage of pale stone, golden in the evening sun, located at the head of a wooded valley where he lived alone. John turned out to be a slight bearded man in a loose white shirt and charcoal tweed bracelet in his early fifties with intense dark eyes which flashed in the twilight matched by a tangled thatch of black hair slightly greying at the temple. He ushered me into a snug stone-walled sitting room where we chatted at length about his life, religious practice and my research interests.

John was remarkably open with details of his life given our brief acquaintance. He explained that he had been married, but had been widowed in his late twenties. He had met his wife at university where they had been drawn together by a mutual interest in meditation and spirituality. He detailed their deep emotional bond, especially their sexual bond. Sex featured high among his topics of conversation and it quickly became apparent that sexual practices were central to John's spiritual practices. ${ }^{6}$ Eventually their personal ritualization of sexual acts led to their mutual exploration of Pagan witchcraft. John was quick to point out that he

(eds.), Redeeming Men: Religion and Masculinities, Louisville, KY: Westminster John Knox Press 1996, 197-208.

6 The role of such intimate confession is often underemphasized in research into men and religion. Note Björn Krondorfer, Male Confessions: Intimate Revelations and the Religious Imagination, Stanford, CA: Stanford University Press 2010, as a refreshing exception to this. 
self-identified as bisexual and that much of his premarital sexual experience was homosexual. John first encountered the Goddess in his early teens when he was learning to meditate. He detailed how he was initially drawn to Buddhism, but his practice was marked with a recurring vision of a female goddess figure whom he identified as the essence of the Earth. In his twenties and thirties he had become involved in a Gardnerian Wiccan coven in Southern England. ${ }^{7}$

John detailed how the coven supported him following the death of his wife. In particular he spoke of the way in which coven elders encouraged him to take refuge in the mythopoetic male archetype of the Horned God as a way of coping with widowhood through a show of masculine strength and stoicism. However, John came to realize that he was losing contact with feminine divinity and, by his mid-thirties, he became disillusioned with his Wiccan practice. He eventually drifted into solo ritual work, still marked by his Wiccan initiation, but increasingly shaped by newfound inspirations in neo-shamanism and Celtic mythology and much more centred around feminine representations of the divine. In particular, he spoke of masturbatory rites in which he would imagine Goddess archetypes whilst, as he put it, 'sacrificing my seed to the feminine divine. ${ }^{8}$ He pointed to a small roughly hewn stone set beside the fireplace - a so-called Sheela na gig -, a grinning female figure holding open with her hands a swollen vulva - as emblematic of this feminization of his spirituality. John discussed the way in which this marked an important turning point in his spiritual and sexual life. Spiritually, he talked about a deepening bond with Mother Earth through his ritual practices which had led him to lead a more ecologically responsible lifestyle. Sexually, John discussed his increasing bisexual orientation after his wife's death. He became interested in Tantra, even undertaking some training as a Tantrika in India with some of the insurance money he received after his wife's death. Sex became an important expression of his spiritual practices with sexual magic becoming ever central to his sexual practices and identity. Female sexual partners brought him closer to what he termed 'sources of feminine power'. The energies raised in the sexual act were

7 Gardnerian refers to the form of Wicca founded and developed by Gerald Gardner (1886-1964), the originator of Wicca (for example Gerald B. Gardner, Witchcraft Today, New York: Citadel Press 2004 [1954]; The Meaning of Witchcraft, San Francisco, CA: Red Wheel/Weiser 2008 [1959]).

8 Note Scott Haldeman, 'Bringing Good News to the Body: Masturbation and Male Identity' in Björn Krondorfer (ed.), Men's Bodies, Men's Gods: Male Identities in a (Post-)Christian Culture, New York, NY: New York University Press 1995, 111-24. 
used as a form of libation to the Mother Goddess, with sexual union with females described in terms of 'sexual alchemy'.

At this point John expressed a preference for sexual submissiveness. This became central to his homosexual practices. He called it 'taking the female role' and observed that he often felt possessed by "divine female energies" when engaged in coition with (usually younger) men. He discussed the way that for the last twenty years his sexual activity had alternated between men and women as a deliberate spiritual strategy:

Sex with men energised me as a 'woman'. My anima went supernova (laughs) ... The only way of grounding this ... of bringing it down to earth, was sex with women. I alternate as far as I can between men and a woman. I've been single for almost thirty years now, but I've had a female tantric partner for the last twelve. She's married, which is rather complicated ... but cuts out, erm, other complications. The men in my life are much more ... erm ... casual than that (laughs). So sex with men charges me up and this is then discharged, so to speak ... Like a lightning bolt (laughs) ... as an offering to Her [The Goddess] through my female partner ... Like Ying and Yang the male and the, erm ... the feminine balance each other and reveal the divine order. I've always felt this since childhood. Male and Female. Male and Female in balance, and me balanced. The sex is ... erm ... therapeutic. It is ritualistic and insightful.

I want to return to the notion of ritual later in this article, but what is clear here is that John was creating an elaborate and idiosyncratic form of spiritual practice based upon the veneration of a goddess which had transformative effects upon his identity. In order to understand the significance of these practices one needs an appreciation of the dynamics of Contemporary Paganism. Let us begin with what we might loosely term Contemporary Pagan Goddess Spirituality.

\section{Goddess Spirituality}

Although precise definition is difficult, one might consider Contemporary Paganisms to be a loose constellation of spiritual paths which are embedded in the ritualistic veneration of nature through which Pagan practitioners access divinity. Definition is bedevilled by the fact that the nature of these relationships to the divine varies both between various Contemporary Pagan traditions and individual practitioners themselves. Indeed, there exists a continuum of belief in the divine which ranges from the polytheism of the reconstructionist Pagan paths such as Heathenism, through the duotheism of Wicca, to an almost monotheistic veneration of a Goddess (or at least a singular female deity representing many Pagan 
goddesses) within Goddess Spirituality. ${ }^{9}$ Given that Contemporary Paganism has partly legitimated itself as a critique of doctrinal monotheisms (particularly Christianity), this latter dynamic might be something of a surprise to non-Pagans. However, it is the androcentric and phallocentric qualities of monotheism with which Goddess spiritualists take issue.

Goddess spirituality - the-a-logy ${ }^{10}$ as opposed to theology - has exerted a significant influence on many of these Pagan paths. This is especially the case of Contemporary Pagan witchcraft where the default position of the duotheism of Mother Goddess and Horned God in Wicca is predominantly practiced in many covens as a thealogical spirituality, with Goddess dominant over God at least at the level of practice, if not liturgy. An example of this within witchcraft is Dianic witchcraft. This is a female only, Goddess-centred spirituality espousing a radical separatist feminism which is often accompanied by a lesbian identity politics. ${ }^{11}$ Since the 1970 s, however, one can discern the emergence of Goddess spirituality as a specific path in its own right outside of mainstream witchcrafts. ${ }^{12}$

Long suggests that the Goddess Movement has three major sources of inspiration: Paganism, feminism and, what she terms, feminist theological forms of Judeo-Christianity. ${ }^{13}$ Indeed recent years has seen both a feminization of Contemporary Pagan liturgy and rhetoric accompanied by an increase in numbers of female practitioners. Indeed

9 Dennis D. Carpenter, 'Emergent Nature Spirituality: An Examination of the Major Spiritual Contours of the Contemporary Pagan Worldview' in James R. Lewis (ed.), Magical Religion and Modern Witchcraft, Albany, NY: State University of New York Press 1996a, 35-72.

10 Naomi Goldenberg, Changing of the Gods: Feminism and the End of Traditional Religions, Boston: Beacon 1979, 96.

11 For example, Zusanna E. Budapest, The Holy Book of Women's Mysteries, Oakland, CA: Susan B. Anthony Coven 1979; Pam Lunn, 'Do Women need the GODDESS? Some Phenomenological and Sociological Reflections' in Feminist Theology 3 (1993), 17-38; Susan Greenwood, Magic, Witchcraft and the Otherworld: An Anthropology, London: Berg 2000.

12 See Asphodel Long, 'The Goddess Movement in Britain Today' in Feminist Theology 5 (1994), 11-39; 'The One or the Many: The Great Goddess Revisited' in Feminist Theology 15 (1997), 13-29.

13 Long 'The Goddess Movement in Britain Today', 13; also note Yvonne Maria Werner, Christian Masculinity for a critical analysis of the perceived feminization of Christianity. 
some studies suggest as many as two-thirds of Contemporary Pagans are women. ${ }^{14}$ As Harvey argues:

In its Pagan manifestation this Goddess-talk has primarily been concerned with the embodied living of life by women. "The Goddess" is not equivalent to "Woman" as archetypal being but more like "the innermost being of women" or "that which exists between women encountering each other". The diversities and particularities of women's lives are significant, not merely some overarching archetypes to which people might be expected to conform. $^{15}$

That is, thealogy fundamentally seeks to go beyond 'hypodermic' models of patriarchal God worship in which participants are expected to conform to some ideal typified by an infallible male deity. ${ }^{16}$ In contra-distinction, female deities empower female practitioners to create new expressions of feminine being which are not rooted in subordination to masculine gods or patriarchy. $^{17}$

\section{Her-Story and Gyn-Ecology}

Such revisions concerning explicitly feminist and egalitarian models of worship by Goddess spiritualists also have had concomitant effects on the way they view the histories of patriarchy and misogyny. That is, goddess worship has often become associated with a revisionist historiography, accompanied by eco-feminist sentiment which equates nature with the feminine body. ${ }^{18}$ Such sentiments have been allied to a feminized version

${ }^{14}$ Dennis D. Carpenter, 'Practitioners of Paganism and Wiccan Spirituality' in James R. Lewis (ed.), Magical Religion and Modern Witchcraft, Albany, NY: State University of New York Press 1996b, 373-406.

15 Graham Harvey, Listening People, Speaking Earth, London: Hurst \& Co. 1997, 69.

${ }^{16}$ For example, Starhawk, The Spiral Dance; Jone Salomonsen, Enchanted Feminism: The Reclaiming Witches of San Francisco, London: Routledge 2002.

17 Ibid.; also Emily Culpepper, 'Roundtable Discussion: If God is God She is Not Nice' in Journal of Feminist Studies in Religion 5:1 (1989), 106-9; Catherine Madsen, 'If God is God She is Not Nice' in Journal of Feminist Studies in Religion 5:1 (1989), 103-5; Judith Plaskow and Carol P. Christ, Weaving the Visions: New Patterns in Feminist Spirituality, San Francisco: Harper \& Row 1989.

${ }^{18}$ For example, Leonie Caldecott and Stephanie Leland (eds.), Reclaim the Earth. Women Speak Out for Life on Earth, London: Women's Press 1983; Mary Daly, Gyn/Ecology: The Metaethics of Radical Feminism, London: Women's Press 1984 [1978]; Susan Griffin, Women and Nature: The Roaring Inside Her, London: Women's Press 1984; Irene Diamond and Gloria Orenstein (eds.), Reweaving the Web: The Emergence of Ecofeminism, San Francisco: Sierra Club, 1990; Judith Plant (ed.), Healing the Wounds: The Promise of Ecofeminism, London: Green Print 1989; Val Plumwood, Feminism and the Mastery of Nature, London: Routledge 1993. 
of history - her-story - which tends to hark back to a hypothesized prepatriarchal utopia of peace, egalitarianism, Goddess worship and matriarchy. ${ }^{19}$ This version of events is often bolstered by (contentious) archaeological evidence. ${ }^{20}$ One sees this version of history most clearly in Riane Eisler's The Chalice and the Blade (1987). Eisler advances the notion that matriarchal 'partnership' models of society preceded and later competed with, patriarchal 'dominator' forms of social organization, and were oppressed by them in the end. Carolyn Merchant anticipates Eisler with a critique of the development of the dual systems of patriarchy and capitalism. She argues for twin historical constructions of woman as nature and man as culture. ${ }^{21}$ She contends that nature came to be viewed as 'wild', 'fecund' and 'disordered' in comparison to the increasingly neat ordered logic of the cultural realm. For Merchant, the conflict between the carnal, 'disordered sexuality' of the female and the cerebral male rationality catalysed the scapegoating of women during the witch craze of the sixteenth and seventeenth centuries - the mythologized 'burning times' which codified the normative gender roles of modernity and the dominance of men. ${ }^{22}$

Whatever the authenticity of these histories, the equation of women and nature has influenced the form, content and direction of both Goddess spirituality and the wider Pagan movement. ${ }^{23}$ In particular, as women attempt to forge new ways of being that are independent of

19 See Charlene Spretnak, Lost Goddesses of Early Greece, Boston: Beacon 1978; Marija Gimbutas, The Goddesses and Gods of Old Europe: Myths and Cult Objects, Berkeley: University of California 1982; The Language of the Goddess, San Francisco: Harper \& Row 1989; Monica Sjöö and Barbara Mor, The Ancient Religion of the Great Cosmic Mother of All, Trondheim: Rainbow 1981; The Great Cosmic Mother, San Francisco: Harper \& Row 1987; Riane Eisler, The Chalice and the Blade: Our Story, Our Future, San Francisco: Harper and Row 1987; Asphodel Long, In a Chariot Drawn by Lions, London: Women's Press 1992. Critiques of the Gimbutasian position have been outlined by, for example, Ronald Hutton, The Pagan Religions of the Ancient British Isles, Oxford: Blackwell 1991, 37-42; Philip G. Davis, Goddess Unmasked, Dallas, TX: Spence Publishing Co. 1998.

20 For example, Gimbutas, The Goddesses and Gods of Old Europe; The Language of the Goddess.

${ }^{21}$ Carolyn Merchant, The Death of Nature: Women, Ecology and the Scientific Revolution, San Francisco: Harper Collins 1980; also Sherry S. Ortner, 'Is female to male as nature is to culture?' in Michelle Z. Rosaldo and Louise Lamphere (eds.), Woman, Culture and Society, Stanford, CA: Stanford University Press 1974, 67-87.

${ }^{22}$ Marianne Hester, Lewd Women and Wicked Witches: A Study of the Dynamics of Male Domination, London: Routledge 1992; Loretta Orion, Never Again the Burning Times: Paganism Revived, Prospect Heights, III.: Waveland Press 1995.

${ }^{23}$ Cf Salomonsen, Enchanted Feminism, 69-70. 
patriarchy, they are also seeking innovative, non-instrumental ways of being with nature. ${ }^{24}$ Thus, traditional correspondences of women with nature and sexuality still remain at the heart of Goddess feminism. The Goddess, for example, is still identified with the primordial mother nature figure, the triple Goddess (of maiden, mother and crone), female sexuality, and the sacred landscape. ${ }^{25}$ Importantly, however, these mythopoetic ecofeminist notions of womanhood have been subject to attack by feminist theorists for their essentialized view of females as sacralized nature. ${ }^{26}$ Despite such critiques, they have been influential in the creation of mythopoetic constructions of masculinity by some Pagan men.

\section{Pagan Men}

The rise of this feminine - and indeed eco-feminist - spiritual idiom within Contemporary Paganisms clearly has implications for Pagan men. They see the feminization of Pagan spiritualities as mirroring broader societal dynamics which have been seen to marginalize certain constituencies of men, particularly masculinities traditionally associated with the working classes. This crisis of masculinity is driven both by the rise of second-wave feminism and the restructuring of work in the West, now rooted in a service-based knowledge economy rather than in traditional heavy industry. ${ }^{27}$ Just as Pagan women have sought to build thealogy upon feminist-friendly mythopoetic foundations, so some Pagan men, against the background of gender crises, have attempted to re-ground their spiritualities in eco-friendly archetypes of 'wild masculinity': a mythopoetic vision of man as wilderness which is congruent with the eco-feminist construction of women as sacred nature. These new androcentric spiritual dynamics are often termed Men's Mysteries. ${ }^{28}$ As Gabriella Smith argues:

24 Long, 'The Goddess Movement in Britain Today', 37.

${ }^{25}$ For example, Starhawk, The Spiral Dance.

26 See Salomonsen, Enchanted Feminism; also, Cecile Jackson, 'Women/Nature or Gender/History? A Critique of Ecofeminist 'Development" in Journal of Peasant Studies 20:3 (1993), 389-418; Huey-Li Li, 'A Cross-Cultural Critique of Ecofeminism' in G. Gaard (ed.), Ecofeminism: Women, Animals, Nature, Philadelphia, PA: Temple University Press 1993, 272-94; Karen Rountree, Embracing the Witch and the Goddess: Feminist Ritual Makers in New Zealand, London: Routledge 2003.

27 See Smith, 'The Wild/Green Man: Exploring the Mythopoetic Legacy within Modern Paganism's Constructions of Gender'; also, Leanne Payne, Crisis in Masculinity, Ada, MI: Baker Books 1995; Anthony W. Clare, On Men. Masculinity in Crisis, London: Chatto and Windus 2000.

${ }^{28}$ Harvey, Listening People, Speaking Earth. 
To shore-up conceptions of manhood many men have turned to archetypal images of masculinity found in New Age neo-Jungian therapeutic and spiritual movements. Men have enthusiastically embraced these movements' essentialist and depoliticized constructions of gender, examples of which are freely harvested from myths and rituals across cultures and historical epochs. ${ }^{29}$

Smith's thesis proceeds to examine the ways in which certain groups of Pagan men have applied two allied masculine mythopoetic Warrior archetypes as a way of invigorating their spiritual practices - respectively those of Robert Bly's Iron John ${ }^{30}$ and the Green Man, which is often synonymous with Wicca's Horned God. ${ }^{31}$ These are, therefore, essentialist readings of masculinity rooted in notions of natural male sexual potency, environmental stewardship and agency built around innate physical and psychological strength.

Given this mythopoetic essentialization of masculinity, Men's Mysteries are obviously beset by the same types of criticism levelled at mythopoetic eco-feminist constructions of women and feminine spirituality. Just as some Pagan women place the idea of the essentialist expressive, nurturing woman at the heart of their practices - a figure akin to the archetypal housewife figure ${ }^{32}$ - essentialism leads some Pagan men to adopt a 'version of manhood which corresponds rather neatly with this society's dominant conception of masculinity. ${ }^{33}$ That is, essentialized gender differences mirror gendered forms of discrimination. ${ }^{34}$ Thus, Smith argues that not only do these new Pagan masculinities seek to entrench gender difference within Contemporary Paganisms, but they also threaten the development of anti-essentialist forms of theaology (for both men and women):

${ }^{29}$ Smith, 'The Wild/Green Man: Exploring the Mythopoetic Legacy within Modern Paganism's Constructions of Gender', 1.

30 Robert Bly, Iron John: A Book about Men, New York: Addison-Wesley Publishing Company Inc. 1990.

31 See Michael Kaufman and Michael S. Kimmel, 'Weekend Warriors: The New Men's Movement' in Harry Brod and Michael S. Kimmel (eds.), Theorizing Masculinities, Thousand Oaks, CA: Sage Publications 1994, 259-88; Ken Clatterbaugh, 'Mythopoetic Foundations and New Age Patriarchy' in Michael S. Kimmel (ed.), The Politics of Manhood: Profeminist Men Respond to the Mythopoetic Men's Movement (and the Mythopoetic Leaders Answer), Philadelphia, Penn: Temple University Press 1995, 44-63.

32 Ann Oakley, Housewife, London: Allen Lane 1974.

33 Kaufman and Kimmel, 'Weekend Warriors: The New Men's Movement', 270.

${ }^{34}$ Scott Coltrane, 'Theorizing Masculinities in Contemporary Social Science' in Harry Brod and Michael S. Kimmel (eds.), Theorizing Masculinities, Thousand Oaks, CA: Sage Publications 1994, 39-60, 45. 
A microcosm of the larger gender crisis exists within Paganism which allows rhetorical appeals for balance to actually threaten feminine and feminist progression. The ... historical focus on goddess primacy breeds a sense of imbalance, and a concomitant masculine crisis within modern Paganism, creating greater impetus to reinvigorate the masculine. ${ }^{35}$

However, despite Smith's fears, evidence suggests that numbers of Pagan men are turning away from androcentric mythopoetic figures such as the Green Man and the Horned God towards female spiritual archetypes. ${ }^{36}$ This shift is an interesting and important development for Pagan scholars. On the one hand, such practices are not rooted in traditional or mythopoetic constructions of masculinity. They are moving away from the essentialism of mythopoetic masculinity to forms of spiritual practice where masculinity and femininity are held in various creative tensions, forming part of what might be termed a spiritual and psychic gestalt. ${ }^{37}$ On the other hand, they appear to be innovative and novel forms of spirituality which are currently un-researched and, as such, deserve academic attention.

\section{Men and the Goddess: A Pilot Cyber-Ethnography}

Following my meeting with John, I conducted a pilot online open-ended questionnaire which was designed to capture a broader snapshot of Goddess-centred male spirituality. Picking up on some of the obvious themes from my discussions with John, the questionnaire was built around a number of relevant issues.

Firstly, there was an introductory section concerning age, sexual orientation, ethnicity, and educational background. Research indicates that Pagans are predominantly educated, middle-class Caucasians with European heritages and I was curious if the profile of these practitioners was different. ${ }^{38}$

Secondly, there were a number of questions posed to the participants about the meaning of goddesses both in their spiritual practices and in their quotidian lives. For example, Is/are there any particular Goddess/goddesses that is/are important in your spiritual practices? Could you name them? How and in what context did you FIRST

35 Smith, 'The Wild/Green Man: Exploring the Mythopoetic Legacy within Modern Paganism's Constructions of Gender', 15.

36 This shift is also noted by Mirsky, 'Men and the Promise of Goddess Spirituality'.

37 This discursive and liturgical shift has been noted within other spiritual traditions as well; note Krondorfer (ed.), Men and Masculinities in Christianity and Judaism.

38 For example, Carpenter, 'Practitioners of Paganism and Wiccan Spirituality'. 
encounter Her/Them? Can you tell me how you usually encounter Her/Them and in what ways? (For example, is it usually during ritual or in everyday life? Do you physically 'see' the Goddesses? How often do you encounter Her/Them?).

The next section asked questions about the relationship between the participants' self-defined spiritual path and Goddesses. The final section asked a series of questions concerning the ways in which participants themselves constructed gender; questions about the dimensions of gendered inequality; and, the potential benefits and/or consequences of Goddess-centred male spirituality at the personal, religious and societal levels. For example, Do you think that your life has changed, or that you have changed as a person since encountering the Goddess/Goddesses? If so, in what ways? Do you view Men and Women has being essentially different? Do you think that currently there is a 'crisis' in masculinity? If so, can you tell me the forms that this crisis takes? Do you think that men still have to change their attitudes and behaviours in order to create better societies? If so, in what ways? (For example towards 'others', the natural world, etcetera.).

Given that this was merely a pilot study, I adopted a simple probability sample built around a snowballing strategy. During the first half of $2005^{39}$, the internet link to the questionnaire was sent to a number of Pagan journals, magazines, e-lists and organizations internationally requesting for participants and that the link to the questionnaire be forwarded to other potential participants. Given this sampling stratagem, I cannot claim that the research is in any sense representative of male Goddess spiritualists, nor can I make any estimation of its incidence. However, in the following sections some of the headline findings will be discussed and theorized.

\section{Men and the Goddess: A Sociological Profile}

The survey was open for a six month window and yielded 216 respondents. Of these 51 per centcame from the USA, 44 per cent from the UK and Ireland, 2 per centfrom both Canada and Australia respectively, and 1 per cent from Continental Europe. It is impossible to say whether this is typical of the MGM as a whole, but I suspect that the over-representation of participants from the UK is an artefact of my sampling methodology and

\footnotetext{
39 Whilst the initial survey for this article was started in 2005 my analysis and conclusions are informed by on-going contact with the MGM and the broader Pagan movement. This will be discussed briefly in the article's conclusion.
} 
my own residence in the UK. The MGM was broadly representative of Contemporary Paganisms as a whole with respect to ethnicity with 93 per cent of respondents identifying themselves as Caucasian with the remainder as 'mixed race'.

Research consistently suggests that Pagans have overrepresentations of educated middle-class professionals. ${ }^{40}$ The MGM, as it turned out, was even more dominated by educated professionals than other Paganisms. Eighty-six per cent of participants were educated to at least undergraduate degree level, with 31 per cent possessing postgraduate qualifications including 6 per cent possessing doctorates. Ninety-seven per cent of respondents classified themselves as either being 'professional' and/or 'self-employed'.

In two final respects the composition of the MGM differed from the demographics of mainstream Paganisms. In terms of sexual orientation, whilst gay men are overrepresented within Paganisms, the overrepresentation was much greater within the MGM. Forty-nine per cent of respondents identified as heterosexual, 45 per cent as homosexual and 6 per cent as bisexual. Likewise, in terms of age, there was a divergence from mainstream Paganisms with a greater representation of younger men, particularly young gay men. Whilst Pagans as a whole are predominantly drawn from the generation of baby boomers (being born between 1946 and 1964), the age profile of my participants was as follows:

$\begin{array}{ll}\text { Age } & \text { Percentage } \\ 60+ & 6 \% \\ 50-59 & 16 \% \\ 40-49 & 28 \% \\ 30-39 & 29 \% \\ 20-29 & 18 \% \\ <20 & 3 \%\end{array}$

For gay respondents, 67 per cent of practitioners were aged 39 or below. In terms of constructions of gender, performance of masculinity, spiritual practice and orientation to goddesses, initial content analyses demonstrate that there do not appear to be significant differences between gay and straight practitioners. In sum, the demography of the MGM appears to be broadly in line with mainstream Paganisms. However, they appear even

${ }^{40}$ Carpenter 'Practitioners of Paganism and Wiccan Spirituality'; Helen A. Berger, Evan A. Leach and Leigh S. Shaffer, Voices From The Pagan Census, Columbia, SC: University of South Carolina Press 2003. 
more educated, have an over-representation of gay men and a younger age profile.

\section{Encountering the Goddess}

Although participants encountered different goddesses from numerous pantheons - Egyptian, Celtic and Romano-Greek goddesses were most commonly venerated - there seemed to be no discernible pattern in such affiliations. Simultaneous affiliations to a variety of goddesses in different pantheons were common to a majority of respondents. Despite this, one can discern a pattern in the religious careers of respondents. A significant majority discussed childhood encounters with a female spiritual being which appeared to lead to a state of cognitive dissonance ${ }^{41}$ in practitioners. On the one hand, it was an empowering experience which was said to catalyse later practice. On the other, many felt both marked out as different and thus isolated and alienated by these experiences. Typically, it was only later in life, most often as young adults when respondents became aware of Contemporary Paganisms, that these dissonant cognitions diminished. Many came to Paganisms through finding books on the subject in local libraries or bookshops. Notices in mind-body- spirit or health shops lead to involvement in local Pagan groups or to magazine subscriptions which eventually led to committed Pagan practice.

Discovering the Pagan community of practice was often liked by respondents to a sense of 'coming home' or 'coming out'. Indeed many of the gay respondents made striking parallels between the two processes: ' came out twice ... first as a gay man, then as a witch.' 'All of the things that the gay community offered me ... refuge, meaning and identity ... Paganism gave me the same thing.' These processes within Paganisms correspond with similar processes of identity politics within Shane Phelan's work on lesbian communities. ${ }^{42}$ Phelan argues that although the lesbian community, like the Pagan community, is diverse, it participates in four major processes which give it the internal consistency of a community:

First, it provides a place that lesbians can be insulated from hostility to their sexual orientation. Second, it furnishes an escape for lesbians from invisibility in the larger community. Third, it supplies models for creating a

${ }^{41}$ For example, Leon Festinger, A Theory of Cognitive Dissonance, Stanford CA: Stanford University Press 1957.

42 Shane Phelan, Getting Specific: Postmodern Lesbian Politics, St. Paul, MN: University of Minnesota Press 1995. 
lesbian persona, helping entrants interpret (or reinterpret) their lives. Fourth, it furnishes an avenue for political activity. ${ }^{43}$

These dynamics are fairly typical of the profiles of Pagans more generally. Dennis Carpenter, for example, reviews the same research outputs by discussing the processes whereby individuals become Pagans. ${ }^{44}$ Both Lynch and Adler describe similar processes whereby people read occult texts which confirm prior mystical experiences and which then attract them to the Pagan community. ${ }^{45}$ In the event, research participants gave numerous reasons for their involvement. Most common was the centrality of feminine divinity, although the need for individual spiritual expression and the reverence for nature were also commonly emphasized by respondents. These findings chime with studies of Contemporary Paganisms more generally. $^{46}$

\section{Constructing Goddesses: Constructing Gender}

Goddesses were often allied to respondents' constructions of nature. However, this is not the essentialized identification of women with nature and men with culture one has seen in connection to Merchant's work or in mainstream thealogy. Although female divinity - and by extension the participants' conceptualizations of nature - was most commonly seen as nurturing and expressive, it also possessed what might be viewed as more traditionally masculine traits within Western culture. That is, goddesses universally possessed physical strength and aggression. Think of Athena, Kali or the Morrígan from Irish mythology. Similarly, nature was seen ubiquitously as both fecund and nurturing - 'traditionally' female qualities - but also 'red in tooth and claw'.

By contrast, human culture, and patriarchy specifically, was seen as the cause of a host of spiritual, moral and ecological problems. Dogmatic uses of rationality and bureaucratization - associated by respondents with the masculine psyche - were almost universally viewed, respectively, to 'close off the mind' to spiritual experiences and to 'intuitive thought', and to atomize society and curb individual liberty. This had two corollaries: firstly, the political orientation of respondents was almost universally

43 Ibid, 87-8, cited and adapted by Helen A. Berger, A Community of Witches, Columbia, SC: University of South Carolina Press 1999, 68.

${ }^{44}$ Carpenter, 'Practitioners of Paganism and Wiccan Spirituality'.

45 Frederick R. Lynch, 'Toward a Theory of Conversion and Commitment to the Occult' in American Behavioral Scientist 20 (1977), 887-908; Margot Adler, Drawing Down the Moon, Boston: Beacon 1986.

46 For example, Carpenter, 'Practitioners of Paganism and Wiccan Spirituality', 397. 
libertarian. This is typical of mainstream Pagans, but was over-represented to a greater extent in the MGM. Secondly, this acted as a critique of normative and essentialized social constructions of gender. Whilst their practices were obviously built around sexual difference (men venerating female deities), they rejected gender essentialism. Typically, masculine traits of excessive aggression and dogmatic rationalism were seen by participants as social constructions historically rooted in the marginalization of female spiritual archetypes in world religions, specifically Christianity. This, for many practitioners, was exacerbated by the rise of modernity. Capitalism was viewed as being built upon masculine traits such as 'ruthlessness', 'aggression' and rational calculation, marginalizing the emotions and intuition. As this respondent observes, 'We are encouraged as men to be closed off emotionally. Spiritually. This is not what men are ... It is modern society that has made this worse ... I was raised a Baptist and Christianity is to blame too ... God is not a male.'

Goddesses were almost universally seen as panentheistic. That is, they are co-extensive with the material universe, but also independent of it - a mid-point on a continuum of belief between deism and pantheism. ${ }^{47}$ This has implications for the way that respondents viewed gender difference. As goddesses manifest a reality that is external to the material world (and human bodies), but which also suffuses it, panentheism is antiessentialist. This was viewed as positive by practitioners, opening them up to better relationships with women, both platonic and sexual; to create a balance between the intuitive, spiritual and emotional sides of their psyche with rational thinking; and, a closer relationship with nature. As this respondent observes:

As a gay man I have many female friends, but those relationships tended to be a little superficial. Maybe artificial is a better word. My work with Isis has changed this. Now we have an understanding which is not just me being seen as a fashion accessory ... Many of my straight friends who do this have had their sex lives and relationships improved too. We are closer in touch with our feelings. It IS is? OK to cry as a man ... I am also in touch with nature. Growing up without belief makes you complacent about the world around you ... Knowing that Isis is THE World changes that.

But what of these practices? Ritual universally lays at the heart of relationships between goddesses and their male adherents, as it does in all Contemporary Paganisms. Ritual is the major way in which gender is

47 Dagobert D. Runes (ed.), Dictionary of Philosophy, Savage, MD: Littlefield, Adams \& Co 1983, 239. 
consciously performed within MGM. ${ }^{48}$ Respondents reported a diversity of rituals within their practices - ranging from simple meditative practices to full scale invocations of goddesses. They shared a common notion of communion with the feminine divine through ideas of possession. Indeed, acts of possession were almost universal among respondents. This is exemplified by a simple ritual working I witnessed during my night at John's house.

\section{A Ritual}

As the shadows began to lengthen in his lounge, John invited me to observe a ritual working in his garden. He ushered me through the French windows into a $V$-shaped garden formed by the sides of a narrowing valley and bounded by dense woodland and brambles. Set in the apex of the garden, screened from the house by a tangle of ragged privet and Russian vine, stood a roundhouse, about four metres in diameter, reminiscent of an Iron Age hut. A roof of rough thatch and bracken, atop wooden supports, rested upon a circular wall of rendered breezeblocks to a height of around two and a half metres. John referred repeatedly to this as his 'pride and joy' and, as he neared it, explained that he had built this ten summers ago as a 'temple to the Earth Goddess'. The temple had to be entered on one's knees, Japanese-style, through a small sliding door, revealing a dark, spacious interior. There was a small circular aperture in the roof set above a wrought iron fire-basket through which a full moon, muted by silver-grey cloud could be glimpsed. Around the hut's windowless perimeter lay a scatter of large cushions of Moroccan shades and design, a curved bench of driftwood and two Buddhist zafus (meditation cushions) in turquoise velvet. I perched upon one of these as John tended to the fire and produced a drum, rather like a large Irish bodhrán, with a flourish from under the bench. John spoke for a short time about the importance of ritual in his spiritual practices. He explained that his Goddess, befitting his Wiccan roots, was an amalgam of many different, predominantly European, goddesses. His liturgical practices were mostly orthodox Wiccan within a neo-shamanic framework. John bade me to relax with closed eyes and then began a slow double drum beat. A minute in, he began to lead me in a guided visualization in a low yet sonorous voice:

48 About 'performing gender', see for example, Judith Butler, Gender Trouble, London: Routledge 1990. 
LISTEN TO THE DRUM. LET IT BECOME YOUR HEART BEAT, YOUR THOUGHTS, YOUR FOOTSTEPS. THE DRUM BECOMES YOUR PATH TO HER. IMAGINE YOURSELF OUTSIDE FACING THE WOODS. THE NECK OF THE VALLEY IS A PORTAL, AN OMPHALOS, A VAGINA. WITH EACH BEAT TAKE A STEP FORWARD INTO THE VEIL OF HER MYSTERIES.

John described the quality of the woods - their cold air, the brush of the undergrowth, roughness of bark - requesting me to relax with each step. After what was perhaps two minutes, he quickened the beat and described a moonlit clearing in the forest. In this clearing a ritual had commenced. A circle of naked women loosely encircled a robed female standing, arms aloft, by a raging bonfire, a pall of smoke spiralling up to the full moon. The drumbeat mirrored the steps of the dancers as they spiralled deosil around the high priestess. ${ }^{49}$ After two, maybe three, revolutions the dancers peeled off and gently coaxed me into the presence of the high priestess. Gently forced me to kneel before her, and she shed her robe and then grabbed my imagined right hand whilst intoning:

I INVOKE THEE, MIGHTY MOTHER,

BRINGER OF SEED AND ROOT,

MAKER OF FLOWER AND FRUIT,

BY LIFE AND LOVE,

AS BELOW, SO ABOVE,

I DO INVOKE THEE TO DESCEND UPON THE BODY OF THIS THY SERVANT AND PRIESTESS.

Whilst she recited this, I was to imagine her tracing a clockwise circular motion with her hand upon mine from her right breast, thence to her left breast, then the abdomen, back to the right breast, then again to the left breast, abdomen, finally ending back at the right breast. I was then invited to imagine the priestess, arms now aloft above me possessed and transformed by the power of John's Goddess:

I INVOKE THEE ISIS. HAIL!

I INVOKE THEE ARADIA. HAIL!

I INVOKE THEE GODDESS. HAIL!

MOTHER OF ALL GODDESSES .HAIL!

WITH MY LIPS WITHOUT FAIL

I INVOKE THE POWER IN THOU,

THE PROTECTION YOUR LOVE WILL ALLOW

IN THIS HUMAN BODY NOW!

49 The Wiccan term for clockwise movement within a rite is deosil. 
Upon finishing this I had to imagine the priestess touching my forehead lightly with her fingertips whilst channelling the Goddess into my body. I was asked to imagine a pulse of female energy entering my forehead and circulating through me. I had to then meditate upon the nature of my masculinity and my relationships with women, the Maiden, Mother and Crone. After two or three minutes of this contemplation I was to imagine the priestess, still touching my forehead, chanting the following:

LISTEN TO THE WORDS OF THE GREAT MOTHER. SHE WHO WAS OF OLD CALLED ARTEMIS, ASTARTE, ATHENE, DIONE, MELUSINE, APHRODITE, CERRIDWEN, DANA, ARIANRHOD, ISIS, BRIDE, AND BY MANY OTHER NAMES. SHE IS THE ONE, SHE IS THE GREAT MOTHER GODDESS THAT CREATED ALL, IS IN ALL AND WILL END ALL.

HEAR HER WORDS IN THE DUST OF WHOSE FEET ARE THE HOSTS OF HEAVEN AND WHOSE BODY IS THE UNIVERSE. I ENTER YOU IN SPIRIT. YOU ARE AN EXPRESSION OF THIS SPIRIT. WOMAN AND MAN. MOTHER AND FATHER. MOON AND SUN. LISTEN WELL!

The priestess continued her soliloquy with me having to repeat each sentence as if making a vow:

YOU ARE NOW ONE WITH ME (line repeated by me),

AND ALWAYS HAVE BEEN (repeat),

I WHO AM THE BEAUTY OF THE GREEN EARTH(repeat),

OF THE WHITE MOON AMONG THE STARS (repeat),

THE MYSTERY OF THE WATERS (repeat),

AND THE DESIRE OF THE HEART (repeat),

CALL UNTO THY SPIRIT AND COME UNTO ME (repeat),

FOR I HAVE COME INTO YOU (repeat),

MAN IS WOMAN, WOMAN IS MAN (repeat),

ALWAYS BE TRUE TO THYSELF (repeat),

FOR I AM REBIRTH AND I AM DEATH (repeat),

FROM ME ALL THINGS PROCEED (repeat),

AND UNTO ME ALL THINGS RETURN (repeat),

FOR I HAVE BEEN WITH THEE FROM THE BEGINNING (repeat).

AND I AM THERE AT THE END (repeat).

At once a fast double drumming sprang from John. Unguided by words, with my head swimming, I opened my eyes to see him, as if possessed, drumming and turning tight circles in a hopping parody of a pirouette or an imitation of a whirling Dervish. I feared at times that he might fall into the embers of the fire such was the frenzy of his dancing. Eyes closed, his drumming winding up into ever faster rhythms, he let out a guttural cry: 
DANCE, LADY, DANCE, IN THE MOONLIT SKY, TO THE THREEFOLD NAME WE KNOW THEE BY.

DANCE, LADY, DANCE, BE PART OF ME, THE WOMAN INSIDE POSSESSED OF THEE.

DANCE, LADY, DANCE, ON THE TURNING EARTH

FOR THE BIRTH THAT IS DEATH AND THE DEATH THAT IS BIRTH.

John repeated this, his dancing and drumming ever more frenzied until, panting loudly, he abruptly stopped - rather like a marionette whose strings have been cut - falling breathlessly onto a pile of adjacent cushions. This marked the end of the ritual.

Anyone with a knowledge of mainstream Wiccan ritual will recognize that elements of this visualization are taking from the ritual of Drawing Down the Moon whereby the high priestess of a coven 'draws down' the Goddess into her body in an act of empowering possession. It often acts as a female counterpoint to the process of Drawing Down the Sun wherein the Horned God possesses the high priest. These acts conform to essentialized mythopoetic gender stereotypes of Pagan ritual practice. The fact that the Goddess possesses the male in John's ritual as a radical inversion of these practices is important here. Although John tailored the ritual for my presence he did say that elements of this lay at the heart of his solo Goddess rituals. As stated, survey participants consistently emphasized the importance of possession, and many of these used modifications of existing Pagan rituals and liturgies to accomplish this. Although I felt something of an outsider during John's ritual there was no doubt in my mind that he was caught up in an ecstatic state of possession. Discussing the ritual with John he touched upon an issue that was common with survey respondents: 'It's through these rituals that I encounter the Goddess. The female energies complete me as a person ... Male and female come together in this sacred encounter ... It's about re-enchantment really. Mind, body, spirit ... Of the World.' This notion that the Goddess completes the male psyche with 'female energies' is crucial to our understanding of MGM practices.

\section{The Interiorization of Otherness}

As the sociological profile of the MGM suggests, practitioners broadly conform to the wider dynamics of other Contemporary Pagan paths. Because of this the MGM shares many features with these spiritualities and can be theorized in congruent ways. Howard Eilberg-Schwartz has 
characterized Contemporary Paganism as part of an Enlightenment legacy which prizes premodern wisdom as a critique of modern life. ${ }^{50}$ The Enlightenment legacy of experimentation is certainly a prominent element of Contemporary Paganisms, particularly the ubiquitous use of 'otherness' as a creative tension which empowers spiritual practices and reenchantment. ${ }^{51}$ Indeed, Eilberg-Schwartz acknowledges that Pagan identity formation is 'firmly rooted in the Enlightenment tradition that seeks to deny the differences between various antitypes and ourselves. ${ }^{, 52}$

Given this, he sees the attempts of Pagans to valorize their premodern heritage as a way of 'dismantling otherness'. ${ }^{53}$ For example, Eilberg-Schwartz sees the deliberate adoption of antitypes by Pagans - for example, the appropriation of the negative term 'witch' by Wiccans, or the adoption of 'druid' - as a way of dismantling difference. ${ }^{54}$ For the MGM, ritual involves the dismantling of gender differences alongside the dismantling of normative constructions of modern masculinity. EilbergSchwartz contends that:

The dismantling of such differences is often accompanied by a concomitant process of interiorization, by which the differences that previously marked us off from our antitypes are now treated as differences within ourselves. The traits of the other may be interiorized as characteristics of our psyche or as aspects of our own cultural, social, and religious practices.

The neopagan desire to use the designation Witch is an example of this modern process of rehabilitating and interiorizing our antitypes. Witches are no longer outside Western civilization but members of it. They have the same professions and the same human needs as other members of our society. The witch is among 'us' just like the Jew, the black, and the woman. ${ }^{55}$

It is in this way that the masculine antitype (goddesses) is interiorized into the profane psyches of practitioners. The socially marginalized female becomes the central motif in the spiritual life of these men and ritual

${ }^{50}$ Howard Eilberg-Schwartz, 'Witches of the West: Neopaganism and Goddess Worship as Enlightenment Religions' in Journal of Feminist Studies in Religion 5:1 (1989), 77-95.

51 See Dave Green, 'Opposites Attract: Magical Identity and Social Uncertainty' in Journal for the Academic Study of Magic 1 (2003), 75-101.

52 Eilberg-Schwartz, 'Witches of the West', 85.

53 Adrian Ivakhiv, 'The Resurgence of Magical Religion as a Response to the Crisis of Modernity: A Postmodern Depth Psychological Perspective' in James R. Lewis (ed.), Magical Religion and Modern Witchcraft, Albany, NY: State University of New York Press 1996, 237-65, 239-40.

54 Eilberg-Schwartz, 'Witches of the West'.

55 Ibid, 85. 
becomes the dominant arena were new forms of masculinity are rehearsed and performed. Indeed, rituals act as loci of liminality where norms are inverted, and where opposites meet and are psychically interiorized. ${ }^{56}$ Gender polarities are common within mainstream Pagan ritual practices, but, as we have seen, such polarities are built upon mythopoetic essentialisms. The MGM is a significant exception to this.

One final point concerns the future of men and masculinities. Research participants saw the ritual interiorization of the female other as a crucial way of breaking down patriarchal structures which stifled the emotional lives of men and culturally marginalized women. The crisis in masculinity was often viewed as the first important expression of such a breakdown and, counter-intuitively, was greeted positively by respondents. The MGM was often perceived by respondents as a vanguard in a new social order based, like Eisler's matriarchy, ${ }^{57}$ upon co-operation rather than gendered domination. As John observed:

Society cannot go on as it has been ... We have to think of ourselves as people these days rather than men as opposed to women. So much that is ... wrong in society is as a result of ... inequality. The planet is threatened because of men. People are poor because of men ... People are dying in wars because of men. The one thing that we can do is change and building ... recognizing the female within ... That female spirit within. Of cultivating that, is a giant step forward.

\section{Conclusions}

Since my survey of 2005 my ongoing researches within the Pagan community reveal an uneasy co-existence between the MGM and mainstream Paganisms. The equation of Pagan men with mythopoetic masculinity still persists in essentialist mainstream discourses, ${ }^{58}$ although, anecdotally, the MGM appears to be growing slowly around the fringes of this mainstream, attracting gay and bisexual men especially. This growth is attested to by an emerging acceptance of male practitioners within Goddess Spirituality as evidenced by many Goddess temples, such as the Glastonbury Goddess Temple in the south-west of England, opening up

${ }^{56}$ See Green, 'Opposites Attract'; also Victor Turner, The Ritual Process: Structure and Anti-Structure, Routledge and Kegan Paul 1969.

57 See Eisler, The Chalice and the Blade.

58 An interesting grassroots example is provided by Silverspear, 'Men and The Goddess', available at http://www.paganpathways-

sheffield.co.uk/?Talk and Discussion Write Ups:Men and the Goddess. Accessed 16 March 2011. 
some or all of their rituals, activities and training to men. Furthermore, I have come across many anecdotal examples of polytheistic male Pagans incorporating goddesses into their personal pantheons of belief and practice. $^{59}$

Whatever the longer-term future of the MGM, it is clear that it marks a 'second wave' of male Pagan practice. Indeed, it is founded upon a rejection of those essentialist constructions of mythopoetic masculinity within the first wave of the Pagan Men's Movement. ${ }^{60}$ Demographically the MGM might conform closely to the broader Pagan movement, but it presents a radicalized version of mainstream dynamics, particularly in the arena of ritual practice. As stated, mainstream Paganisms are often constructed around essentialized polarities of gender. Wiccan ritual practice, for example, is empowered by the magical dynamic between masculinity and femininity (as exemplified by Drawing Down The Moon). This symbiosis of gender - the encounter between essentialized notions of masculinity and femininity - lies at the heart of Wiccan notions of mystery and the overt sexualization of much of its ritual practice. By contrast, the MGM retains this sexualization, but its dynamic is built around a different sexual antitype - the channelling of female deity by male Pagans. Contextualizing this within the work of Eilberg-Schwartz, the interiorization of the other is a product of the Enlightenment. Thus, the MGM is philosophically modern, but simultaneously possesses gender identifications which critique normative modern masculinities. Paganisms are often simplistically theorized as postmodern forms of spiritual reenchantment. ${ }^{61}$ The rise of the MGM complicates this, meaning that more research is needed to unpick its epistemic roots. Its simultaneous embrace and rejection of the modern demonstrates that more nuanced sociological understandings are required of both second wave male practitioners and the Pagan movement as a whole. The MGM reveals that a perspective is required which goes beyond procrustean categories such as 'modern' and 'postmodern' and which seeks to understand the interaction between Paganisms and these sociological antitypes.

59 See, for example, Pagan Perspective, 'Should a male Pagan worship the Goddess?', http://www.youtube.com/watch?v=j5GbALahllA. Accessed 19 June 2012.

60 Therefore to understand the roles and practices of men within Paganisms researchers need to open up to polysemic meanings of masculinity and its relationship to religion; note Krondorfer (ed.), Men and Masculinities in Christianity and Judaism; also Stephen B. Boyd, W. Merle Longwood and Mark W. Muesse (eds.), Redeeming Men: Religion and Masculinities, Louisville, KY: Westminster John Knox Press 1996.

${ }^{61}$ For example, Orion, Never Again the Burning Times; Carpenter, 'Emergent Nature Spirituality'. 